\title{
Szolidaritás járvány idején
}

\section{Solidarity in times of pandemia}

\author{
Grajczjár István1 - Pauló Edit² \\ https://doi.org/10.51624/SzocSzemle.2021.2.3 \\ Beérkezés: 2021. 03. 24. \\ Átdolgozott változat beérkezése: 2021. 07. 19. \\ Elfogadás: 2021. 08. 30.
}

\begin{abstract}
Összefoglaló: E tanulmány a 2017 és 2020 közötti időszakra vonatkozóan vizsgálja a szolidaritás változását Magyarországon a munkapiaci szempontból aktív korú kérdezettek reprezentatív mintáin. Emellett arra igyekszik választ adni, hogy az egyes inkluzív és exkluzív szolidáris és nonszolidáris csoportok hogyan jellemezhetők járvány idején, a csoport-hovatartozás hogyan köthető a járvány okozta munkafeltételekben bekövetkező változásokhoz, a kormánnyal való szimpátiához, a beszerzendő vakcinákba vetett bizalomhoz, az oltakozási hajlandósághoz és az annak hátterében meghúzódó kockázatvállaló, illetve oltásóvatos motívumokhoz. A kutatási kérdések arra irányulnak, hogy hogyan változtak a vizsgált időszakban a szolidaritásklaszterek gyakoriságai, illetve mely szociodemográfiai tényezők, a lezárásokkal kapcsolatos munkapiaci tapasztalatok, oltakozási attitűdök és politikai szimpátiák hozhatók összefüggésbe a szolidaritással és a különböző szolidaritáscsoportokkal járványhelyzetben. Az elemzés során multinomiális logisztikus regresszió segítségével jellemezzük Kriesi módosított modellje alapján létrehozott inkluzív és exkluzív szolidáris, illetve nonszolidáris klasztereket az aktív korúak között. Eredményeink szerint a vizsgált időszakban markánsan növekedett a makroszolidáris törekvések támogatottsága, valamint az inkluzív és kisebb mértékben az exkluzív szolidárisok aránya, a kirekesztő attitűdöké pedig tendenciózusan csökkent, csakúgy, mint az exkluzív nonszolidáris csoport megoszlása. Ugyanakkor az exkluzív szolidáris és nonszolidáris csoportok tagjai azok, akik körében szignifikánsan alacsonyabb az oltási hajlandóság, amely egy komoly egészségügyi vészhelyzetben az aktív kockázatvállalás hiányára utal, s többek között megnehezítheti a nyájimmunitás elérését is.
\end{abstract}

Kulcsszavak: Covid-19-járvány, szolidaritás, inkluzív és exkluzív attitűdök, politikai orientáció

\begin{abstract}
This study examines the changes in solidarity in Hungary over the period of 2017-2020 on a representative sample of active aged respondents. It also seeks to answer questions on how inclusive and exclusive solidarity and non-solidarity groups are characterised during an epidemic, how group membership is related 1) to changes in working conditions caused by the epidemic, 2) to affinity for the government and 3) to willingness to vaccinate and the underlying risk-taking and vaccination-averse motives. The research questions focus on how the prevalence of solidarity clusters changed over the period
\end{abstract}

1 Milton Friedman Egyetem, email: grajczjar.istvan@uni-milton.hu

2 Milton Friedman Egyetem, email: pauloedit@gmail.com 
under study, and which sociodemographic factors, labour market experiences related to lockdowns, vaccination attitudes and political affinities are associated with solidarity and different solidarity clusters in epidemic situations. The analysis uses multinomial logistic regression to characterise inclusive and exclusive solidarity and non-solidarity clusters among active aged individuals based on modified Kriesi's model. Our results show a significant increase in the support for macro-solidarity and a marked increase in the share of inclusive and, to a lesser extent, exclusive solidarity clusters over the period under study. At the same time, it shows the declining level of exclusionary attitudes and so, the decreasing distribution of the exclusive non-solidarity cluster. However, it is the members of the exclusive solidarity and non-solidarity groups who have significantly lower vaccination intentions, which indicates a lack of active risk-taking behaviours in a serious health emergency situation and may, among other things, make it more difficult to achieve herd immunity.

Keywords: Covid-19 epidemic, solidarity, inclusive and exclusive attitudes, political orientation

\section{Bevezetés}

A Covid-19-pandémia világszerte több, mint négy és félmillió ember életét követelte, sokak életveszélyes állapotba kerültek, a felgyógyultak egy részének akár hosszú távú szövődményekkel is számolnia kell, nem is szólva arról, hogy tartós védettséget a betegségen átesettek sem élveznek. A megoldást a kialakult krízishelyzetre szinte az egész világon többek között egy biztonságos és hosszú hatású vakcina kifejlesztésétől, illetve a nyájimmunitás elérésétől várják a szakemberek.

A Covid-19-járvány és annak következményei azonban nemcsak az orvostudományt vagy az epidemiológusokat állították komoly kihívások elé, de társadalmi, gazdasági és politikai hatásaik okán a társadalomtudósokat is. A fertőzésveszély, a korlátozások és lezárások következtében sokakban tartós félelem és szorongás alakult ki, beszúkültek, illetve az online térbe szorultak korábban megszokott, jól múködő kapcsolatok, sok esetben fenyegetetté vált a megélhetés biztosítása, a munkahelyek megtartása, a családok megélhetése. Vannak természetesen olyan társadalmi csoportok is, akiket érdemben nem érintett a járvány, sem egészségi állapotukat, sem megélhetésüket tekintve. A kutatások sokrétűek, szerteágazóak, legyen szó az embertársainkba és az intézményeinkbe vetett bizalomról, a munkavégzés új formáiról, az egyenlőtlenségek növekedéséről, a vakcinációval kapcsolatos attitűdökről, az összeesküvés-elméletek terjedéséről vagy a társadalmi szolidaritásról.

Jelenlegi tudásunk szerint a globális járványok leküzdéséhez fontos feltétel a nemzetközi térben értelmezhető nyájimmunitás kialakítása. A kifejlesztett vakcinák globális szintú, szolidaritáson alapuló elosztása (COVAX) azonban kudarcba fulladni látszik, a szegényebb régiók vélhetően csak egy-két év múlva jutnak megfelelő mennyiségú oltóanyaghoz (Szócska 2021). Európa és azon belül az egyes országok szintén versenyezni kényszerülnek a megfelelő mennyiségú és minőségű vakcináért, ami alapjaiban rengeti meg a szolidaritásalapú törekvéseket, és életre hívja az ún. vakcinanacionalizmus jelenségét is (Örkény 2021). Szolidaritás nélkül azért is kétséges a jelenlegi vírushelyzetben a nyájimmunitáshoz szükséges átoltottság elérése, mert a koronavírus elleni oltás beadatása nem kötelező, így az állam ál- 
tal biztosított oltóanyag felvételéhez a lakosság részéről aktív, szolidarisztikus értelemben vett kockázatvállalás szükséges. Fontos kérdéssé válik, hogy a szolidaritáscsoportok bíznak-e a vakcinákban, hajlandóak-e beoltatni magukat, vagyis mennyire jellemzi őket az aktív kockázatvállalás, illetve az oltásóvatosság egy egészségügyi vészhelyzetben.

Ebben a tanulmányban egyrészt a 2017 és 2020 közötti inkluzív és exkluzív attitűdök és szolidaritásformák változását vesszük górcső alá Magyarországon, elsősorban a makroszintű, intézményesített szolidaritással kapcsolatos attitűdökre, mint az állami újraelosztás támogatására, illetve az egyenlő esélyek biztosítására fókuszálva a munkapiaci szempontból aktív korú kérdezettek reprezentatív mintáin. Másrészről a 2020-as mintán multinomiális regresszió segítségével megvizsgáljuk, hogy a szociodemográfiai és járványpercepciós változókat kontroll alatt tartva a munkafeltételekben bekövetkezett változások, a kormánnyal való szimpátia és a vakcinákba vetett bizalom, az oltakozási hajlandóság és kockázatvállalás, valamint az oltásóvatosság mennyiben befolyásolják az egyes szolidaritáscsoportokba kerülés esélyét. A makroszintű/intézményesített, az újraelosztás támogatásához kapcsolható attitűdök és a kormánnyal és az állam által kínált vakcinákkal szembeni bizalom vizsgálata kiemelt fontosságú, hiszen többek között a hatékony védőoltás biztosítása és igazságos, a veszélyeztetett csoportokba tartozást figyelembe vevő, szolidaritásalapú elosztása is állami, azaz makroszintû́ feladat. Emiatt fontos kérdéssé válik az, hogy a makroszolidaritás támogatottsága növekszik-e járvány idején, illetve a makroszolidáris attitűdök találkoznak-e az aktív kockázatvállalói intencióval, vagyis a polgárok hajlandók-e a vakcináció által, aktív módon kivenni a részüket a tágabb értelemben vett közösség védelméből, illetve a nyájimmunitás kialakításából, amit a közösség érdekében történő aktivitást igénylő szolidaritásmotívumnak tekinthetünk (lásd általánosságban erről: European Observatory on Health Systems and Policies - Xavier 2018).

Részletesebben tehát arra keressük a választ, hogy pandémia idején 1) hogyan változnak az inkluzív és exkluzív attitűdök, illetve a szolidaritásformák gyakoriságai, és 2) ezeket a különböző szolidaritásformákat

- mely szociodemográfiai tényezők magyarázzák, különös tekintettel a társadalmi egyenlőtlenségeket talán legmarkánsabban megtestesítő szociális státuszra,

- hogyan befolyásolja a lezárások következtében megroppanó munkapiaci helyzet és a megélhetés/életminőség/egészségi állapot veszélyeztetettsége, valamint a pandémiával/vakcinációval kapcsolatos tájékozottság, illetve kifáradás,

- hogyan hozhatjuk összefüggésbe az oltakozási hajlandósággal, illetve az aktív kockázatvállalással és az oltásóvatosággal,

- milyen mértékben befolyásolja a kormánnyal való elégedettség és az állam által kínált vakcinákba vetett bizalom 


\section{Elméleti megfontolások}

\section{Szolidaritás}

A közösségi összetartozásnak, a társadalom integrációjának - amely a szociológia megszületése óta foglalkoztatja a szociológusokat - egyik kötőanyaga a szolidaritás. Émile Durkheim (2000 [1893]) a szolidaritás két alaptípusáról beszél. A mechanikus szolidaritás a preindusztriális társadalmakra jellemző, alapja a közös érték, a kollektív tudat, a hasonlóság: ez morális kötelezettséget ró az egyénre. Az organikus szolidaritás a modern társadalmakban a foglalkozási specializálódás következtében alakul ki, hiszen kölcsönös függőség van a társadalom tagjai között, senki sem élhet a másik munkája nélkül.

Bayertz (1999) szerint a szolidaritás arra sarkallja az embereket, hogy saját szükségleteik kielégítését az össztársadalmi érdekek miatt korlátozzák, szükség szerint kölcsönös segítséget nyújtsanak az egyének egymás számára (Gesthuizen et al. 2014). Zulehner, Denz, Pelinka és Tálos hangsúlyozzák (1996: 54), hogy a szolidaritás a társadalmi igazságosság központi fogalma, amelynek három fő szintjét különböztethetjük meg. A mikroszolidaritás a közeli hozzátartozókra, barátokra, a számukra nyújtott segítségre vonatkozik. A következő szint, a mezoszolidaritás kifejeződhet a munkahelyi kapcsolatokban, az érdekképviseleti szervezetek vagy akár a civil szervezetek munkájában, míg az efölött álló makroszolidaritás a kollektív egymásrautaltság, a bizalom és a segítségnyújtás szintje (Beecher 1986, Stjernø 2005: 28), amelynek célja a társadalmi egyenlőtlenségek csökkentése. A makroszolidaritás kiterjed a jóléti állam újraelosztási rendszerének múködésére, a különböző régiók felzárkóztatására, de migrációs és menekültkérdésekkel kapcsolatos intézkedések területére is (Grajczjár et al. 2019), és túlmutat a nemzeti, etnikai, vallási határokon.

A szolidaritás szintjei szorosan összefüggenek olyan dimenziókkal, mint a szolidaritás alapja/terjedelme (Stjernø 2005). A szolidaritás alapját az képezi, hogy az egyén kivel, kikkel tud azonosulni. Ez lehet egy szúk csoport a hasonlóság vagy a kölcsönös függés okán, de bővülhet például a politikai és vallási hovatartozás következtében, elméletileg akár egészen az emberiségre kiterjedő szintig. Az egyén identifikációs képességének korlátai azonban kijelölik a szolidaritás határait is, mivel megszabják, hogy ki az, aki beletartozik a szolidaritásközösségbe. Ahogy Becker, Eckert, Kohli és Streeb megjegyzik (2004), a szolidaritás koncepciója nem univerzalisztikus, egy adott csoporthoz való tartozás korlátozza a szolidaritást (Goes 2015: 54).

Stjernø megközelítése szerint a szolidaritás egyszerre bevon és kirekeszt, integrál és megoszt (Stjernø 2005: 85), ezért megkülönbözteti az inkluzív és exkluzív szolidaritást. Mivel az in-groupnak, és ezzel együtt a szolidaritásnak is vannak határai, az exklúzió valamilyen formája szinte elkerülhetetlen (Smith-Sorrell 2014: 235). Az exklúzió alapja lehet etnikai, vallási, kulturális vagy területi megkülönböztetés, de társadalmi státusz, tulajdonított érdem, nemi orientáció vagy identitás mentén is 
kialakíthatja az in-group azokat a határokat, amelyek mentén meghatározza és védi önmagát az out-grouppal szemben (Tragl 2000: 137; Goes 2015: 54).

Hondrich és Koch-Arzberger (1992) további elemeket is hangsúlyoznak a szolidaritás előfeltételeként: ilyenek a közösen képviselt meggyőződések és értékek, valamint az igazságossági igény mellett az interakciók gyakorisága, a társadalmi közelség, a társadalmi bizalom és a közös külső fenyegetettséggel szembeni védelem (például ökológiai, járványügyi katasztrófák idején). Az említett faktorok befolyásoló ereje mint szolidaritásmező müködik, amely inkább nagyon vegyes, szabadon választott, de gyakran erős szociális kötődések mentén és már kevésbé hagyományos, kényszerü közösségi kötelékként jelennek meg. A szolidaritás érzése leginkább közösségi vészhelyzetben, mint amilyen egy világjárvány, csap át aktivitásba (Hondrich-Koch-Arzberger 1992: 20). Zulehner et al. (1996: 52) szerint - többek között a fentiek okán - a szolidaritás nem korlátozódhat egyszerűen egy értékrendre, hanem aktivitást igényel.

Hondrich és Koch-Arzberger (1992: 22) megállapítják, hogy a szolidaritás választás kérdése: az egyén dönthet arról, hogy szolidárisan viselkedjen, vagy sem, és arról is, hogy inkluzív vagy exkluzív formáját válassza a szolidaritásnak. A szolidaritás inkluzív formájának legfőbb célja a közösség jóléte és a társadalmi és gazdasági javak igazságos elosztása. Pusztán az etnikai, nemzeti és más megkülönböztető kritériumok alapján történő elosztás ezért nem tekinthető igazságosnak, ha például nem veszi figyelembe a rászorultság dimenzióját (Zulehner et al. 1996).

Reßler (2002) hangsúlyozza a jóléti állam fontosságát, amely eredeti célja szerint óvja a gyengébbet, és törekszik az esélyegyenlőség megteremtésére. Ezzel szemben áll a neoliberalizmus versenylogikája, amely kifejezetten antiszolidáris. Reßler megállapítása szerint a baloldali pártok támogatói inkább az inkluzív-emancipatorikusuniverzalisztikus, míg a jobboldaliak inkább a szolidaritás bizonyos kritériumokra épülő exkluzív formáját támogatják.

Kriesi (2015) modellje ötvözi a fenti szakirodalmi megállapításokat. Az inklúzióexklúzió tengelye azt határozza meg, hogy a szolidaritás kire vonatkozzon, vagyis stjernøi értelemben kit vonjon be, és kit rekesszen ki (Stjernø 2005). A másik tengely a szolidaritás és neoliberalizmus végpontjait jelöli ki, ami hasonló Reßler megközelítéséhez, amely a neoliberalizmust a jóléti állammal állítja szembe (Reßler 2002). Ezek besorolását az 1. ábra mutatja be. 


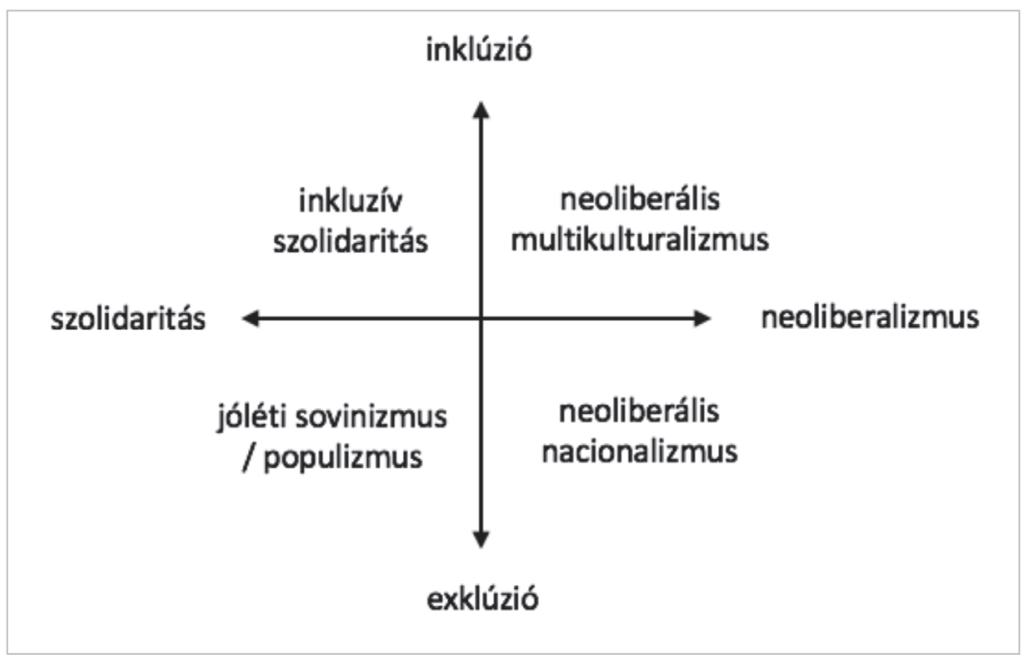

Forrás: Kriesi 2015

Grajczjár et al. (2019) azonban egy módosítást javasol az eredeti modellen, amelyben a szolidaritás ellenpólusát a nonszolidaritás jelenti. A módosítás nemcsak azért fontos, mert a szolidaritás valódi ellenpólusa inkább az általános értelemben használt nonszolidáris magatartás (a neoliberalizmusé pedig inkább a szocializmus), hanem azért is, mert a neoliberalizmus túlságosan érték- és ideológiatelített fogalom, vagyis egy vizsgálat kiindulópontjaként érdemes olyan modellt alkalmazni, amely nem tartalmaz lehetséges magyarázatokat a kialakítandó klaszterekre nézve.

\section{2. ábra: Módosított Kriesi-modell.}

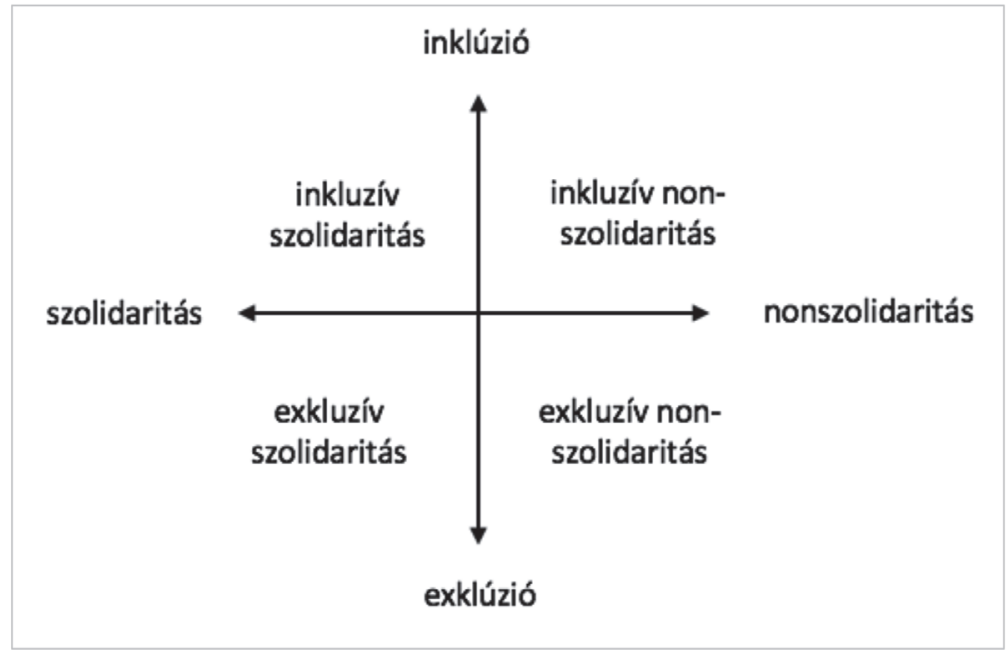


A szolidaritástengelyt, ahogyan a későbbiekben látni fogjuk, Reßler, Zulehner és Kriesi álláspontját követve, makroszolidaritásként operacionalizáltuk, hiszen jelen kutatás során nem a mindennapi szociabilitásra voltunk kíváncsiak, hanem az intézményesített szolidaritás iránti attitűdökre, mint amilyen a jóléti állam általi újraelosztás vagy a nemzetközi szinten történő redisztribúció, kiegészítve az általános, emberek közötti egyenlő bánásmód és esélyegyenlőség univerzális értékének támogatásával. Ahogyan Denz (2003) írja, a makroszolidaritás támogatása nem a közvetlenül megtérülő érdekekre támaszkodik, hanem azok helyzetének javítására, jólétére törekszik, akik kívül esnek a személyes érdekek horizontján (lásd még: Bierhoff 2002: 295), és olyan értékek, normák és erkölcsi megfontolások mentén ragadható meg, amelyek a bajbajutottak/szükséget szenvedők segítését célozzák, állampolgárságtól, etnikumtól, vallási hovatartozástól, szexuális orientációtól, egészségi állapottól függetlenül. A makroszolidaritás intézményesült formában a jóléti állam vagy államok közösségének (lásd EU) újraelosztási mechanizmusain keresztül múködik, ahol a közösség a kockázatokat (adóztatás, szociális transzferek stb. segítségével) megosztja a tagok között (Bayertz 1999: 37), amely így többek között politikai küzdelmek tárgyává is válik.

\section{Inklúzió és exklúzió járvány idején}

Az előző fejezetben említett inkluzív és exkluzív tengely kialakításához érdemes itt néhány fontos elméleti megfontolást rögzítenünk, hiszen e tengelyt - ahogyan a későbbiekben látni fogjuk - a szociális dominancia orientáció, a jóléti sovinizmus/ populizmus és a tekintélyelvűség attitűdhármasának segítségével hozzuk létre. Lényegében az említett exkluzív attitúdökkel kapcsolatos kutatások mutatnak rá arra, hogy lakossági reprezentatív mintákon a kérdezettek gyakran genetikai, kulturális, etnikai, anyagi, morális vagy egyéb vélt vagy valós alapon határozzák meg, hogy mely csoportok „hivatottak/érdemesek” arra, hogy sikeresen küzdjenek meg a változásokkal (jelen pandémia idején a betegséggel, vagy a lezárások következményeivel), illetve mely csoportok „feláldozhatóak” (lásd még: Sik-Zakariás 2021; Tragl 2000: 137; Goes 2015: 54). ${ }^{3}$

Pratto, Sidanius, Stallworth és Malle 1994-ben publikálták nagy hatású tanulmányukat a szociális dominancia orientációról. Definíciójuk szerint az SDO egy olyan általános orientáció, amelynek segítségével az egyén a hierarchikusan rendeződő csoportközi kapcsolatokat tartja kívánatosnak szemben az egyenlősítő törekvésekkel, vagyis a szolidaritás exkluzívabb formáit az inkluzív formákkal szemben. Az

3 Az egyenlőtlenséget támogató ideológiáit hierarchialegitimáló mítoszoknak is nevezzük (Pratto et al. 1994), amelyekre jellemző, hogy minél szélesebb körben fogadja el és tartja ezeket magától értetődőnek egy adott társadalom, annál nagyobb befolyással vannak a társadalmi múködés alapmechanizmusaira. Minél közelebb áll egy legitimáló mítosz a társadalomban elfogadott alapvető értékekhez és normákhoz, annál inkább konzerválódik, és annál jobban meghatározza a társadalompolitikai alapelveket is: vagyis annál erőteljesebb a hatása, minél inkább összhangban van az adott társadalom fő vallási, társadalmi, politikai, gazdasági ideológiáival (Grajczjár-Kenéz 2015). A legitimáló mítoszok befolyásolják a társadalmi értékek csoportok közötti elosztását (az inkluzív és exkluzív szolidaritás mértékét), mert a „kevésbé jó/érdemtelen/gyenge” embereknek kevesebb társadalmi érték juttatását tartják elfogadhatónak (Pratto et al. 1994). Ezek az értékek lehetnek: vagyon, hatalom, státusz, presztízs, a munkahely vagy az egészség is. 
elmélet szerint a társadalmak törekszenek arra, hogy minimalizálják a csoportközi konfliktusokat, ezért olyan ideológiát támogatnak, ami igazolja egyes csoportok hatalmát más csoportok fölött (Pratto et al. 1994). A magas SDO-szinttel jellemezhető jelenséget új rasszizmusnak is hívják. Az új rasszizmus értelmezése szerint az alá- és fölérendeltség az eltérő adaptációs képességek miatt alakul ki, amelyek biztosítják az egyén túlélését a folyamatosan változó világban és válságos helyzetek során. Ezek az adaptációs képességek lehetővé teszik, hogy privilegizált társadalmi csoportok a változások miatt kialakuló új lehetőségeket másokkal szemben, mások kárára is ki tudják aknázni (Mileti et al. 2002). Járványhelyzetekben az egészség válik fontos társadalmi értékké, ha tetszik, a túlélés zálogává, az SDO pedig abban a meggyőződésben jelenik meg, hogy a "gyengének/alacsonyabbrendünek” tekintett csoportok áldozattá válása természetes folyamat.

Jellemző példaként említhetjük Choma és munkatársai (2021) Kanadában, az Egyesült Királyságban és az Egyesült Államokban végzett vizsgálatát. Kutatásuk azt a kérdést feszegette, hogy ideológiai és pszichológiai változók mennyiben tudták előre jelezni az egyén véleményét a járvánnyal kapcsolatos intézkedésekről, az egészségügyi előírásokról és a kollektív fellépésről. Azt találták, hogy a magas SDOértékkel rendelkezők kevésbé éreztek empátiát azokkal, akik elkapták a vírust, kevésbé tartották hatékonynak az intézkedéseket, és ezzel összefüggésben alacsonyabb hajlandóságot mutattak arra, hogy elfogadják a megelőző intézkedéseket, betartsák az egészségügyi előírásokat, vagyis támogassák a makroszolidaritásra irányuló törekvéseket.

A második jelenség a Kriesi által is említett jóléti sovinizmus/populizmus attitűdje. A jóléti sovinizmus elsősorban a bevándorlókkal, menekültekkel szemben, míg a jóléti populizmus a hazai kisebbségekkel, szegényekkel, hajléktalanokkal („a jóléti állam potyázóival”) szemben jelenik meg (Hentges-Flecker 2006: 140; Kriesi 2015). E jelenség eredetileg a skandináv új-jobboldali pártok hívószavaiban tört felszínre, amelyek a magas adók és a túlfútött bürokrácia ellen lázadtak, és amely jelenség később szociokulturális színezetet kapott, és szegényellenességgel, valamint bevándorlásellenességgel párosult (Rydgren 2006: 165). A média és a szélsőséges, populista jobboldal által felkarolt jelenség azután komoly társadalmi búnbakkeresésbe torkollott, a menekülteket, bevándorlókat, etnikai kisebbségeket, NGO-kat, segítő szervezeteket, szociáldemokratákat stb. kárhoztatva a társadalmi problémákért (Rydgren 2006: 168-172). Ahogyan Kaindl hangsúlyozza, ez a bűnbakképzés a későbbiekben a fogyatékkal élőkre, a munkanélküliekre, az egyéb inaktívakra is átterjedt, és sok helyütt ma már a középosztályra és szakszervezeti körökre is jellemző (Kaindl 2006: 72).

A jelenlegi pandémia során egy példaként említve Dániában a lakosság reprezentatív mintáján vizsgálták a Covid-19-fertőzöttekkel kapcsolatos jóléti és egészségügyi sovinizmust (healthcare chauvinism) befolyásoló tényezőket (Larsen-Schaeffer 2020). A megkérdezetteknek arról kellett dönteniük, hogy egy hipotetikus helyzetben kinek jár- 
jon inkább kórházi kezelés. Ha a beteg születése óta Dániában élt, akkor kevésbé sújtotta soviniszta ítélet, és ezt nem befolyásolta az sem, ha a muszlim kisebbséghez tartozott. Ha azonban csak egy éve vándorolt be az országba, akkor kevésbé tartották kórházi kezelésre érdemesnek, különösen akkor, ha muszlim nevet viselt a beteg. A kutatók arra következtetésre jutottak, hogy a közös teherviselés hiányának feltételezése felerősíti a soviniszta hozzáállást, ami katalizátorként hat a rasszista attitűdökre.

A harmadik, számunkra fontos elmélet a tekintélyelvűségről szól, amelynek megszületése a frankfurti iskolához kötődik (Adorno et al. 1950). A kutatások jelenlegi állása szerint az autoriter személyiség az alárendeltség és a dominancia utáni vágy kettőségének kombinációjából fakad. Az autoriter személyiség számára vonzó a szigorú morális értékek és a jogrend védelme, illetve a „normálistól” eltérően, „erkölcstelenül” viselkedő személyekkel szembeni, akár agresszív fellépés, legyenek azok bevándorlók, az elit tagjai vagy a jóléti állam nyakán „élősködők”. A tekintélyelvú doktrínák nemcsak egyenlőtlenségpártiak, de irracionálisak is: a hierarchia a múltban, a tradíciókon, vagy Isten akaratán alapul, így megfellebbezhetetlenül érvényes. A tekintélyelvű emberek zárt, fekete-fehér gondolkodásmódjára jellemző, hogy szigorú határok mentén támogatandó in-groupra és elutasítandó out-groupra osztják világukat (Aiello-Areni 1998).

A jelenlegi Covid-19-pandémia során Hartman és munkatársainak vizsgálata (2021) arra mutatott rá, hogy a koronavírus általi fenyegetettségérzés megerősítette a tekintélyelvű attitűddel rendelkezők etnocentrista és bevándorlásellenes felfogását. Az Egyesült Királyságban és Írországban végzett kutatásukban a fenyegetettségérzést a Covid-19-vírussal szembeni szorongásként operacionalizálták, és megállapításuk szerint az ellenséges attitűd akkor is az out-group felé irányul, ha fenyegetettségérzés nem külső csoporttól, hanem a láthatatlan vírustól ered.

Az exkluzív attitűdök és az oltási hajlandóság összefüggésével kapcsolatban azonban eltérő eredményekre jutnak a kutatások. Murphy, Vallières, Bentall és munkatársainak (2021) az Egyesült Királyságban és Írországban végezett vizsgálata szerint a Covid-vakcinát elutasítók és a hezitálók csoportjai eltérő társadalmi, gazdasági és politikai jellemzőkkel írhatók le a két országban, azonban a pszichológiai profiljuk hasonló. E csoportok egyik jellegzetessége a tekintélyelvűség és a magas SDO-érték, vagyis előnyben részesítik a társadalom hierarchikus felépítését.

Ezzel ellentétben Soral és Bilewicz (2021) által végzett, három országra kiterjedő, nagyszabású vizsgálatban a tekintélyelvűség és a magas SDO-szint szignifikánsan, de ellentétes előjellel jelezte előre az oltási hajlandóságot: a tekintélyelvűség magasabb, a magas SDO-szint pedig alacsonyabb oltási hajlandósággal járt együtt. A kutatók szerint a tekintélyelvű személyiség számára az oltás válik a társadalom megvédésének eszközévé, mert az egyén az oltás beadatásával nemcsak saját magát, hanem a környezetében élöket is védelmezi. Ezzel szemben a magas SDO-szintű egyének az oltást inkább az elnyomás eszközének tekintik, az oltás felvételét pedig a gyengeség beismerését jelentő cselekedetnek. 


\section{Szolidaritás a Covid-19-pandémia idején}

E kézirat lezárásának időpontjáig még nem jelentek meg olyan közlemények, amelyek a (makro)szolidaritás támogatottsága és a vakcinációs hajlandóság kapcsolatával, illetve a különböző szolidaritáscsoportok oltakozással kapcsolatos attitűdjeivel érdemben foglalkoztak volna. Ugyanakkor jelentősen bővültek a szolidaritás és a Covid-19-pandémia közötti kapcsolatról szóló tapasztalataink. Aschauer és Mayerl (2019) megállapítása szerint társadalmi nehézségek/krízisek esetén inkább csökken a szolidaritás, mivel rendszerint szúkül az a kör, amelyre a szolidaritás korlátozódik, vagyis a szolidaritás exkluzívvá válik. Alexander (2012) egy korábbi írása szerint azonban egy kollektív trauma éppen ellenkező hatást érhet el: megerősíti a szolidaritást, kitágítja a „mi” közösségét.

Alexander elméletét támasztja alá Carlsen, Toubøl és Brincker (2021) vagy Koos és Bertogg (2020) kutatása, akik Dániában, illetve Németországban vizsgálták a civil társadalom segítségnyújtását a közösségi oldalak használatával a Covid-19-járvány alatt. A vizsgált közösségimédia-csoportok azért jöttek létre, hogy a segíteni szándékozók olyan rászorulókat is elérjenek, akik kívül esnek a családi és baráti körön. $\mathrm{E}$ kutatások szerint a támogatás mértéke mellett a segítők száma is nőtt, közel negyedük újonnan vett részt szolidaritási akciókban, vagyis a koronavírus-krízis „jelentős szolidaritási kapacitást szabadított fel” (Carlsen et al. 2021: 127).

A makroszolidaritás támogatását vizsgálta Németországban Koos és Leuffen (2020) kutatása, amelyben a résztvevők egy elképzelt szituáció rövid leírását kapták, és arra kellett válaszolniuk, hogy mennyire támogatnának egy egészségügyi vagy gazdasági mentőcsomagot, ha annak a kedvezményezettje egy másik német szövetségi tartomány, EU-tagállam vagy EU-n kívüli állam lenne. A kutatás szerint a válaszadók összességében inkább támogatnák az egészségügyi segítséget, mint a gazdaságit, és elsősorban egy másik német tartományt segítenének. Kiderült a felmérésből az is, hogy az EU-tagállamoknak inkább egészségügyi segítséget, míg egy EU-n kívüli országnak inkább pénzügyi segítséget biztosítanának. Az eredmények tehát azt mutatják, hogy nem egyértelmű a társadalmi nehézségek, a krízis és a szolidaritás inkluzív formáinak kapcsolata: a német tartományok egyrészt erősebb támogatást kapnának, ugyanakkor segítségtípusonként eltérő, hogy ki tartozna a szolidaritás körébe.

Voicu és munkatársai (2021) azt vizsgálták, hogy milyen hatással volt a Covid19-járvány a szolidaritásra három országban: Spanyolországban, Magyarországon és Romániában. A 2020 áprilisában készült adatfelvételük eredményét a European Values Study 2017-2018-ban készült vizsgálatával vetették össze. A szolidaritást azzal mérték, hogy a válaszadók mennyire aggódnak bizonyos csoportok életkörülményei miatt. A kutatás azt bizonyította, hogy a pandémia alatt nőtt a szolidaritási hajlandóság, különösen ha a válaszadó szűkebb környezetében valaki elkapta a vírust, vagy ha elszigeteltséget, mentális törést tapasztalt a lezárások következtében.

Örkény Antal (2020) hangsúlyozza, hogy a kötelező járványügyi intézkedések betartása miatt az embereknek nő az államtól való függősége, ami végső soron a 
döntéshozók, szakemberek, politikusok iránti bizalmatlanságot növelheti. A Covid19-járvány következtében a társadalom nagyobb része azt érezheti, hogy veszélybe került az élete, csökken a jóléti szintje, és kiszolgáltatottsága növekszik. Ebben a helyzetben a társadalmi szolidaritás gyakorlása a középrétegre hárulna, azonban itt is növekszik az egzisztenciális bizonytalanság (Örkény 2020), amit erősít a munkapiaci védelem hiánya. A helyzetet az is nehezíti, hogy a járvány elhúzódása miatt erősödik az emberek kifáradása, ami alacsonyabb járványpercepcióhoz és csökkenő szolidaritáshoz vezethet.

Sik Domonkos és Zakariás Ildikó (2021) a járvány első hulláma után, 2020 júliusában végeztek kutatást. Vizsgálták a segítségnyújtás célcsoportjait, rendszerességét és tartalmát is (ápolás, gondoskodás, főzés; mentális jólét biztosítása; anyagi segítség). Fontos eredmény, hogy a szolidaritásakciók elsősorban az „érdemesnek tartottnak/megmenthetőnek” minősített rászorulókat célozták, a legelesettebbek a nekik tulajdonított érdemtelenség és esélytelenség miatt jórészt kiszorultak a szolidaritási körből. A pandémia előrehaladtával a szolidaritás kiterjedt a tágabb közösségre is, elsősorban azokra, akiket a járvány leginkább veszélyeztetett, vagy részt vettek a járvány elleni küzdelemben (idősek, egészségügyi dolgozók). A kutatás során leírt öt klaszter közül a legnagyobb csoport (38,8 százalék) a közönyös kívülállók voltak: magasabb státuszuk mellett nem érintette őket a járvánnyal együtt járó gazdasági/munkaerőpiaci krach, nem érezték a megbecsültségük csökkenését. A kevésbé szerencsésekkel nem volt közös tapasztalatuk, ezért azok segítését nem érezték rájuk tartozó ügynek. Ezzel szemben a jótékony szerepbe integráltakra (9,5 százalék) az volt jellemző, hogy átlag feletti mértékben dolgoztak a járvány által érintett segítő ágazatokban (oktatási, egészségügyi, vagy szociális területen), politikai preferenciájukat tekintve pedig a 2010 utáni nem jobboldali ellenzékkel azonosultak. A két csoportot tehát politikai értékbeli, szakmai etikai megfontolások, illetve a járvány hatásának személyes tapasztalatai is elválasztották egymástól (Sik-Zakariás 2021).

\section{Módszertan}

A Milton Friedman Egyetemen 2017 nyarán a szolidaritással kapcsolatban az aktív korúak 1000 fős mintáján a nemzetközi SOCRIS-projekt ${ }^{4}$ keretében folytattunk telefonos (CATI) lekérdezést, amelynek az inkluzív és exkluzív szolidaritással kapcsolatos kérdéseit 2020. november 15. és 25. között egy 1002 fővel készült húszperces, szintén telefonos (CATI) kérdőív segítségével megismételtük (COVAC-projekt). Az országos minták a főbb szociodemográfiai jellemzőkre, nemre, korra, iskolai vég-

4 A SOCRIS-projekt (ANN 120360) 2016 és 2020 között térképezte fel az emberek társadalmi-gazdasági változásokra adott reakcióit és politikai orientációit Ausztriában és Magyarországon, bemutatva a válság társadalmi kohézióra és demokratikus viszonyokra gyakorolt hatását. A kutatás során feltártuk, hogy az említett folyamatok hogyan hatnak a kirekesztő, nacionalista és xenofób attitűdökre és hogyan vezetnek el a populista radikális jobboldal iránti szimpátiához. A projekt ugyanakkor bemutatta azt is, hogy a válság alatt hogyan erősödnek fel az inkluzív, demokratikus, szolidaritásra épülő politikai orientációk, ezzel új elméleti keretben vizsgálva az inkluzív és exkluzív politikai orientációk jelenségét. Részletesebben lásd: www.socrisproject.com 
zettségre, településméretre és régióra voltak reprezentatívak. A 2020-as kutatás főként Covid-19-vakcinációval kapcsolatos problémákra fókuszált.

Az adatelemzést két részre bontottuk: egy időbeli összehasonlító és egy keresztmetszeti vizsgálatra. Az időbeli összehasonlító (trend)vizsgálat a makroszolidaritás, az inkluzív és exkluzív attitűdök, illetve Kriesi módosított modellje nyomán az e dimenziók mentén létrehozott inkluzív és exkluzív szolidáris és nonszolidáris klaszterek arányainak változására fókuszált 2017 és 2020 között. A keresztmetszeti vizsgálat során pedig a 2020-as mintán kialakított szolidaritásklasztereket hoztuk kapcsolatba az oltakozási hajlandósággal, illetve a kockázatvállalással és az oltásóvatossággal. (Hiszen hiába osztja el az állam a vakcinákat akár a lehető legigazságosabban, ha a polgárok inaktívak maradnak, és sem maguk, sem mások érdekében nem vállalják az oltakozással járó esetleges kockázatokat.) A szolidaritásklasztereket jellemeztük továbbá a beszerzendő vakcinák iránti bizalommal és a kormányszimpátiával, valamint egyéb, a tájékozottságot, a veszélyeztetettség percepcióit és a pandémia következtében bekövetkező negatív munkapiaci változásokat mérő változókkal multinomiális logisztikus regresszió segítségével.

\section{Operacionalizálás}

\section{Függő változók}

Ahogyan az elméleti részben már emellett érveltünk, a szolidaritás-nonszolidaritástengelyt a makroszolidaritás támogatása mentén operacionalizáltuk.

A makroszolidaritás egyéni szintű támogatását mind az összevont adatbázison, mind a 2020-as adatbázison főkomponensek segítségével mértük, amelyek a következő változókból álltak (a megmagyarázott hányad mindkét esetben 48 százalék volt):

- A gazdag országok lakóinak különadót kellene fizetniük annak érdekében, hogy segítsék a szegényebb országok lakóit;

- A magyar kormánynak lépéseket kellene tennie a jövedelmi különbségek csökkentése érdekében;

- Fontos számomra, hogy az emberek egyenlő bánásmódban részesüljenek, és azonos esélyeik legyenek.

Az inkluzív és exkluzív tengely kialakításához a jobboldali radikalizmus irodalmából kölcsönöztük a korábban említett három attitűdöt, amelyek mentén határozottabban kikristályosodni véltük az exkluzív orientációt: a szociális dominancia orientációét, ${ }^{5}$ a tekintélyelvúségét ${ }^{6}$ és a jóléti populizmusét ${ }^{7}$ (lásd még: Politi et al.

5 Az SDO-t a következő kijelentésekkel való egyetértés/elutasítás mentén mértük: Nincs mit tenni, az a természet rendje, hogy a gyengék essenek áldozatul a vírusnak; Vannak emberek, akik alacsonyabbrendűek másoknál; Néha át kell gázolnunk másokon ahhoz, hogy elörejussunk az életben. Főkomponens, megmagyarázott hányad: $48,5 \%$.

6 A tekintélyelvűség indexet a következő kijelentésekkel való egyetértés mentén alakítottuk ki: A tekintély tisztelete és az engedelmesség a két legfontosabb erény, amelyeket a gyerekeknek meg kell tanulniuk; Erős vezetőkre van szükségünk, akik megmondják, mit tegyünk.

7 A jóléti populizmus indexet a következő kijelentésekkel való egyetértés mentén mértük: Amikor kevés a munkahely, a munkaadóknak előnyben kellene részesíteniük a magyarokat más népcsoportokkal szemben; Szociális ellátást csak azoknak kellene adni, akik fizetnek adót és egyéb hozzájárulást. 
2020, Grajczjár et al. 2021). E három aggregált változót egyetlen (másodlagos) főkomponensre rendeztük (megmagyarázott hányad: 50,4 százalék).

\section{Magyarázó változók}

A szokásos szociodemográfiai változók (nem, kor, településtípus) mellett az iskolai végzettség, a foglalkozási pozíció (a munkanélküliek esetében a legutolsó foglalkozási pozíció) ordinális skálára történő transzformációját követően és az egy főre jutó jövedelem segítségével hoztuk létre a társadalmi státusz változót (eredetileg Lenski 2013). ${ }^{8}$

Fontos szerepet kapott a magyarázatok között a lezárások következtében bekövetkezett munkapiaci érintettség, ${ }^{9}$ a kifáradás/tájékozódás ${ }^{10}$ percepciója, a járvány súlyosságának (veszélyeztetettség) érzékelése ${ }^{11}$ és az állam által beszerzendő vakcinába vetett bizalom, ${ }^{12}$ amelyek vagy egy, már korábban említett kutatásban, vagy elméleti szinten magyarázó tényezőnek bizonyultak (vö.: Örkény 2020, Sik-Zakariás 2021, Pizzaro et al. 2020), illetve kontrollváltozóként szántunk nekik szerepet.

Fontos szerepet szántunk továbbá a kormányszimpátiának ${ }^{13}$ (vö.: Reßler 2002, Sik-Zakariás 2021), valamint az oltakozási hajlandóság ${ }^{14}$ mellett az oltásóvatosság$n^{15}{ }^{15}$ is, vagyis annak, hogy kész-e a kérdezett aktívan kivenni a részét egy vészhelyzet során a közösségi kockázatvállalásból, a társadalmi felelősségvállalásból.

\section{Eredmények}

Eredményeink tárgyalásának első részében érdemes felhívni a figyelmet a 2017 és 2020 közötti, a makroszolidaritást, a kormány támogatottságát, illetve az inkluzív és exkluzív attitűdöket érintő változásokra (1. táblázat). A vizsgált időszakban a makroszolidaritást támogató attitűdök szignifikánsan javultak az országban, ahogyan a kormányzat iránti szimpátia is, bár ez utóbbi egy négyfokú skálán így sem mondható magasnak. Az SDO és a jóléti populizmus szintje egyértelmúen csökkent, míg a tekintélyelvűségé, ha kismértékben is, de szignifikánsan növekedett. Összességében tehát az inkluzivitás erősödött Magyarországon a Covid-19-pandémia első évét is magában foglaló időszakban.

\footnotetext{
8 Fökomponens, megmagyarázott hányad: $54,8 \%$

9 Munkaérintettségi index: érintette-e elbocsátás, bércsökkentés, munkaidő-csökkentés, fizetés nélküli szabadság.

10 A kifáradás/tájékozódás index: Milyen gyakran tájékozódik a járvánnyal, lehetséges védőoltásokkal kapcsolatos hírekről?; Ritkábban vagy gyakrabban tájékozódik a járvánnyal, lehetséges védőoltásokkal kapcsolatos hírekről, mint tavasszal?

11 Veszélyeztetettség percepciója: Ön szerint hol tartunk jelenleg a Covid-19-járvány lefolyását illetően Magyarországon?; Önre vagy az Önnel egy háztartásában élők életminőségére nézve mennyire jelent veszélyt a Covid-19-járvány akár életveszély, akár szövődmények, akár a megélhetés biztosítása szempontjából?; Tart Ön attól, hogy Ön vagy az Önnel egy háztartásában élők elkapják a koronavírust? Főkomponens, megmagyarázott hányad: $51 \%$.

12 Mennyire bízik abban, hogy a magyar állam hatékony és biztonságos védőoltást képes kínálni a lakosság számára? (Négyfokú Likert-skála.)

13 Hogyan értékeli az Orbán-kormányt és politikai álláspontját? (Négyfokú Likert-skála.)

14 Beoltatná-e magát egy Magyarországon engedélyezett, koronavírus elleni vakcinával? (Négyfokú Likert-skála.)

15 Nekem mindegy, hogy kit oltanak be az első körben, csak ne én legyek az (négyfokú Likert-skála).
} 


\begin{tabular}{|c|c|c|c|c|c|c|}
\hline & $\begin{array}{c}\text { Nonszolidaritás- } \\
\text { szolidaritás-tengely } \\
\text { (makroszolidaritás } \\
\text { főkomponens) }\end{array}$ & $\begin{array}{l}\text { Kormány- } \\
\text { szimpátia } \\
\text { (négyfokú } \\
\text { Likert-skála) }\end{array}$ & $\begin{array}{c}\text { SDO } \\
\text { fökompo- } \\
\text { nens }\end{array}$ & $\begin{array}{l}\text { Jóléti po- } \\
\text { pulizmus } \\
\text { standardi- } \\
\text { zált index }\end{array}$ & $\begin{array}{l}\text { Tekintélyel- } \\
\text { vúség stan- } \\
\text { dardizált } \\
\text { index }\end{array}$ & $\begin{array}{c}\text { Inkluzív-exk- } \\
\text { luzív tengely } \\
\text { (SDO; jóléti } \\
\text { populizmus, } \\
\text { tekintélyelvű- } \\
\text { ség) főkom- } \\
\text { ponens }\end{array}$ \\
\hline 2017 & $-0,192$ & 2,17 & 0,242 & 0,120 & $-0,057$ & 0,137 \\
\hline 2020 & 0,234 & 2,59 & $-0,294$ & $-0,146$ & 0,070 & $-0,166$ \\
\hline
\end{tabular}

Mivel korreláció a makroszolidaritás és az inkluzív-exkluzív-tengely között nem mutatható ki (Pearson: 0,04, sig: 0,08), vagyis a tengelyeink függetlenek egymástól, bizakodva nézhetünk a klaszterelemzés elé.

Kriesi korábban bemutatott, módosított modellje (lásd a 2. ábrát) volt a segítségünkre a szolidaritásmintázat kialakításában, ahol az inkluzív-exkluzív-tengely és a szolidaritás-nonszolidaritás-tengely keresztezéséből négy csoport hozható létre: az inkluzív szolidárisoké, az exkluzív szolidárisoké, az inkluzív nonszolidárisoké és az exkluzív nonszolidárisoké. A csoportképzés során a k-középpontú klaszterelemzést használtunk, ahol az egyik tengelyt a korábban leírt (makro)szolidaritás változókból képzett főkomponens, míg a másik tengelyt a szociális dominancia fökomponens, a jóléti populizmus, valamint a tekintélyelvűség indexekből létrehozott ún. másodlagos főkomponens alkotta (az összevont adatbázison 14 iteráció során, pairwise modellépítés segítségével jött létre a stabil klaszterstruktúra; $N=1821$ ).

A létrejött klasztereket a 2. táblázat szemlélteti. Minél magasabb a pozitív érték az alábbi táblázatban, annál jellemzőbb az adott csoportra az exkluzivitás és/vagy a szolidaritás. Minél kisebb ez az érték (negatív értékek), annál kevésbé jellemzők ezek az adott csoportra.

\section{2. táblázat: A k-means klaszterelemzés eredményei az összevont adatbázison ( $N=1821)$}

\begin{tabular}{c|c|c|c|c} 
& $\begin{array}{c}\text { exkluzív szolidari- } \\
\text { tás }(28 \%)\end{array}$ & $\begin{array}{c}\text { inkluzív szolidari- } \\
\text { tás }(24 \%)\end{array}$ & $\begin{array}{c}\text { inkluzív } \\
\text { nonszolidaritás } \\
(17 \%)\end{array}$ & $\begin{array}{c}\text { exkluzív } \\
\text { nonszolidaritás } \\
(31 \%)\end{array}$ \\
\hline $\begin{array}{c}\text { nonszolidaritás- } \\
\text { szolidaritás- } \\
\text { tengely }\end{array}$ & 0,89109 & 0,64885 & $-1,22137$ & $-0,63303$ \\
\hline $\begin{array}{c}\text { inkluzív-exkluzív- } \\
\text { tengely }\end{array}$ & 0,81028 & $-1,10132$ & $-0,62205$ & 0,47029 \\
\hline
\end{tabular}

A 2. táblázat mutatja be a létrejött klaszterstruktúrát és zárójelben az összevont adatbázison megfigyelhető klasztergyakoriságokat. Ahogyan láthatjuk, az exk- 
luzív szolidárisok jellemezhetők a legerősebb makroszolidáris/redisztribúciós attitűdökkel, de egyben ők a leginkább kirekesztőek is. Az inkluzív szolidárisok makroszolidaritás-támogatása is határozottnak mondható, és a kirekesztő attitűdök elutasítása közöttük a legerősebb. Az inkluzív nonszolidárisok a legerőteljesebben elutasítóak a redisztribúcióval és az egyenlő esélyek támogatásával szemben, ugyanakkor a második tengelyen mért attitűdjeik határozottan inkluzívnak mondhatók. Az exkluzív nonszolidárisok pedig relatíve mérsékelt exkluzivitás mellett elutasítják a makroszolidaritás támogatását.

A 3. táblázat mutatja be a fenti csoportok méretének változását 2017 és 2020 között. Ahogyan láthatjuk, az inkluzív szolidáris csoport a duplájára hízott, az exkluzív szolidárisok csoportja pedig 8 százalékkal nőtt a vizsgált időszakban, mialatt az exkluzív nonszolidárisok aránya 42 százalékról 18 százalékra zsugorodott. $\mathrm{Az}$ inkluzív nonszolidárisok prevalenciája érdemben nem változott. A rendelkezésre álló változószettel egyértelmúen bizonyítani ugyan nem tudjuk, de további vizsgálatok tárgyává tehetjük annak elemzését, hogy e markáns változások mennyiben köszönhetőek a pandémiának és a pandémia következtében a korábbi kutatások által bemutatott, de inkább mikro- és mezoszinten vizsgált szolidaritásváltozásoknak Magyarországon.

3. táblázat: A szolidaritásklaszterek változásai az összevont adatbázison (chi négyzet: 151,6; $p<0,000, N=1821$;

\begin{tabular}{|l|c|c|} 
& 2017 & 2020 \\
\hline exkluzív szolidaritás & $24 \%$ & $32 \%$ \\
\hline inkluzív szolidaritás & $16 \%$ & $33 \%$ \\
\hline inkluzív nonszolidaritás & $18 \%$ & $17 \%$ \\
\hline exkluzív nonszolidaritás & $42 \%$ & $18 \%$
\end{tabular}

Arra azonban nyílik lehetőségünk, hogy 2020-as klasztereinket többek között a pandémia munkapiaci következményeinek hatásaival, a beszerzendő vakcinákba és a kormányba vetett bizalommal, az oltakozási hajlandósággal és kockázatvállalással, illetve az oltásóvatossággal jellemezzük, és ezáltal próbáljunk meg magyarázatot adni az egyes szolidaritáscsoportok járvány alatti viselkedésére.

\section{Logisztikus magyarázó modell}

Amennyiben magyarázó modellt szeretnénk építeni e szolidaritáscsoportok jellemzésére, multinomiális regressziót alkalmazhatunk, amelyben az inkluzív szolidáris csoport jellemzőit vetjük össze egyenként a többi csoport jellemzőivel. ${ }^{16}$

16 Nagelkerke pseudo R2 =0,302; McFadden $=0,126$. 
Először nézzük meg azonban azt, hogy mit tudunk a referenciacsoportról. Az inkluzív szolidárisok átlagosan 45 évesek (a legidősebb csoport az aktív korú mintán), tájékozottságuk/kifáradásuk, veszélyeztetettségpercepciójuk és az állam által beszerzendő vakcinákba vetett bizalmuk átlagos, oltási hajlandóságuk azonban az átlagnál magasabb, és a nők felülreprezentáltak körükben (53 százalék). Emellett az oltakozás mögött meghúzódó kockázatvállalásuk erős, az átlagosnál urbanizáltabb környezetben laknak, társadalmi státuszuk a legmagasabb a négy csoport közül, ugyanakkor kormányzati szimpátiájuk a leggyengébb. Fontos megjegyezni továbbá, hogy az inkluzív csoportokat érintette leginkább a munkadepriváció (legerősebben az inkluzív nonszolidáris csoportot, őket követik az inkluzív szolidárisok).

4. táblázat: Logit modell

\begin{tabular}{|c|c|c|c|c|c|c|c|c|c|}
\hline \multirow[t]{2}{*}{$\begin{array}{l}\text { referenciacsoport: } \\
\text { inkluzív szolidáris }\end{array}$} & \multicolumn{3}{|c|}{ exkluzív szolidáris } & \multicolumn{3}{|c|}{ exkluzív nonszolidáris } & \multicolumn{3}{|c|}{ inkluzív nonszolidáris } \\
\hline & $\mathrm{B}$ & Sig. & $\operatorname{Exp}(B)$ & $\mathrm{B}$ & Sig. & $\operatorname{Exp}(B)$ & B & Sig. & $\operatorname{Exp}(B)$ \\
\hline nem &,- 284 & 323 &, 753 &,- 445 & 149 & ,641 & ,395 & ,314 & 1,484 \\
\hline kor &,- 021 & , 109 & 980 &,- 021 & 127 & ,979 &,- 056 & ,002 & 946 \\
\hline településméret &,- 002 & ,989 & ,998 &,- 050 & 674 & ,951 &,- 118 & ,439 & 888 \\
\hline társadalmi státusz &,- 624 & ,000 &, 536 &,- 396 & ,023 & ,673 &,- 082 & ,714 & 922 \\
\hline munkaérintettség &,- 824 & ,006 & ,439 &,- 902 & 010 & ,406 & 184 & ,596 & 1,202 \\
\hline tájékozottság/kifáradás & ,066 & 695 & 1,068 &,- 239 & , 173 & ,787 &,- 143 & ,523 & 866 \\
\hline veszélyeztetettség percepciója &, 168 & 295 & 1,183 &, 024 & ,890 & 1,024 &,- 142 & ,524 & 868 \\
\hline oltási hajlandóság &,- 391 & 017 & ,676 &,- 358 & 042 & 699 &,- 186 &, 412 & 830 \\
\hline $\begin{array}{l}\text { bizalom a beszerzendő vakci- } \\
\text { nában }\end{array}$ &,- 106 & 613 & 899 &, 141 &, 542 & 1,151 &, 551 & 081 & 1,736 \\
\hline kormányszimpátia & ,908 & ,000 & 2,480 &, 845 & ,000 & 2,328 &, 528 & 051 & 1,695 \\
\hline $\begin{array}{l}\text { kockázatvállalás vs. } \\
\text { oltásóvatosság }\end{array}$ & ,295 & ,037 & 1,343 & 011 & 941 & 1,011 &,- 207 & ,253 & 813 \\
\hline
\end{tabular}

Ahogyan a 4. táblázatból kitűnik, az inkluzív szolidáris referenciacsoporthoz képest a többi csoport nem mutat szignifikáns eltérést a társadalmi nem, a településméret, a kifáradás (vs. tájékozottság/tájékozódás), a veszélyeztetettségérzés vagy az állam által beszerzendő vakcinákba vetett bizalom terén (az inkluzív nonszolidárisok valamivel fiatalabbak, mint az inkluzív szolidárisok). Mindkét inkluzív csoport társadalmi státusza az exkluzívakéhoz képest magas, csakúgy, mint a munkaérintettségük: vagyis az inkluzív csoportok magas státuszuk ellenére az exkluzívakhoz képest megszenvedték a lezárásokat munkapiaci értelemben (munkaidő-csökkenés, elbocsátás, bércsökkenés, fizetés nélküli szabadság). További fontos eredmény, hogy az inkluzív szolidárisokhoz képest mindkét exkluzív csoport kormányszimpátiája jóval erősebb (több mint kétszeres eséllyel kerülnek a kormánnyal szimpatizáló szavazók e klaszterekbe). Az oltási hajlandóság terén az inkluzív csoportok egymáshoz hasonlók, azonban - különösen az exkluzív szolidáris csoport - jóval kockázatkerülőbb (oltáselutasítóbb), amit megerősít az a tény is, hogy amennyiben vállalnák is az oltakozást, akkor sem az első körben tennék azt, hanem maguk elé tessékelnének 
másokat. (Mivel az oltakozási hajlandóságot kontoll alatt tartottuk, mindegy, hogy oltakozók, hezitálók vagy nem oltatók csoportjainak oltásóvatosságát hasonlítjuk össze, az exkluzív szolidárisok a többi klaszter tagjaihoz képest minden csoportban kerülik a kockázatvállalást.)

Látható, hogy a munkaérintettség hiánya és vélhetően az ebből fakadó empátiahiány (lásd Choma et al. 2021, Sík-Zakariás 2021), valamint az alacsony szociális státusz az exkluzív klasztereknél kombinálódik az oltás gyakoribb elutasításával. Hiába a többi klaszter tagjaival azonos mértékủ (és egyébként országosan magas) tájékozottsági szint és veszélyeztetettségpercepció, még a relatíve erős kormányszimpátia és az állam által beszerzendő vakcinákba vetett (átlagosan magas) bizalom sem képes ezen a félelmen és empátiahiányon áttörni. Különösen az exkluzív szolidárisok 32 százalékos tömbjének oltásóvatossága és kevéssé aktív, kockázatkerülő magatartása lehet egy egészségügyi vészhelyzetben aggasztó. Az exkluzív szolidáris csoport esetében ugyanis azt sem szabad elfelejtenünk, hogy e csoport tagjai egyszerre mutatnak erős redisztribúciót és egyenlőséget támogató attitűdöket, és ezzel egyidejűleg kirekesztő, jóléti populista, hierarchiapártoló és autoriter beállítódásokat. E látszólagos ellentmondás feloldását ismeri a szakirodalom, és tribalizmussal, szektariánus egyenlősítő törekvésekkel, ön- és csoportfelemeléssel jellemzi azt az empátiahiányos magatartást (lásd például Csepeli et al. 2011), amely a társadalmi hasznokat maximalizálja, de a közös kockázatvállalást kerüli, illetve a közösségi szolidaritást legfeljebb a szűk in-groupra vonatkoztatja: minden más csoporttal szemben támogatja a kirekesztést és/vagy a hierarchizáló álláspontot, ami egy világjárvány esetében mások feláldozhatóságát jelenti, hiszen fizikai valójukra leginkább kísérleti laborként tekint. Ebbe az önös érdekeket előnyben részesítő attitűdkészletbe mint attitüdinális keretbe illesztve az alacsony szociális státuszt mint objektív deprivációt (amely az önvédő álláspontot erősíti) és a pandémia általi munkapiaci érintettség hiányát (amely a szakirodalomban említett empátiahiányt vélhetően tovább növeli), összességében érthetőbbé válik e csoport aktív kockázatvállalást elutasító, csak a saját, illetve a saját csoport érdekeit védő, vagy ha tetszik, minden más csoportnál oltásóvatosabb magatartása, amelyen az erős kormányszimpátia ellenére a kormányzat oltástámogatása sem volt képes az adatfelvétel idején (még) változtatni. Vagyis e csoport tagjai másoktól várják a megoldást: vagy az állam teljes szigorával lép fel a normaszegőkkel szemben, esetleg tovább szigorít (akár újabb munkahelyek elvesztése árán is, amely, mint láthattuk az exkluzív szolidárisokat kevéssé mozgatja meg), vagy a „többiek” beoltatják magukat, és az esetlegesen elért nyájimmunitás vagy lecsengő járvány miatt az exkluzív szolidárisok „megúszhatják” az oltakozást, vagy addig várnak ki a vakcinációval, amíg a lehető legbiztonságosabb megoldást, egy hatékony gyógyszert vagy vakcinát választhatnak. Ami az oltásóvatosságot és oltáselutasítást illeti, velük szemben az inkluzív nonszolidáris csoport is kockázatvállalóbb (mondhatni, erősebb vakcinációszolidaritást mutat), hiszen az erősen individualista, az újraelosztást elutasító álláspont nem kíván egy- 
oldalúan hasznot húzni mások szükséghelyzetéből, kockázatvállalásából és/vagy az állami gondoskodásból: egyénileg vállalják a kockázatot, és emellett inkluzív álláspontot foglalnak el. Vagyis az inkluzív csoportokra a magasabb státuszból (magasabb iskolai végzettségből) és a munkaérintettségből/megélhetési kényszerből fakadó empátia, az inkluzivitás nyitott gondolkodást, méltányos kockázatvállalást és teherviselést támogató attitűdjei, valamint a vakcinákba vetett általános bizalom hathatott pozitívan az aktív vakcinációs hajlandóság kialakításában, míg az exkluzív csoportokra a kormányzat pozitív vakcinációs álláspontja sem hatott eléggé motiválóan ahhoz, hogy az oltakozási motívumok között az aktívabb kockázatvállalást és mások védelmét is figyelembe vegyék.

\section{Konklúzió}

Kutatásunk eredményei rávilágítottak arra, hogy a tanulmány születését megelőző három évben nőtt a makroszolidaritás támogatottsága Magyarországon, ami hozzájárult az inkluzív szolidáris csoport megduplázódásához is (a pandémia alatt növekvő szolidaritásról Magyarországon lásd még Voicu et al. 2021 kutatását). Az állami vakcinabeszerzés és -elosztás támogatásának szempontjából ez mindenképpen biztató eredmény, amely vélhetően a Covid-19-pandémiának is köszönhető. Ezt a feltételezést alátámaszthatja Alexander (2012) elmélete is, miszerint egy kollektív trauma kitágítja a „mi” közösséget, és jelentős szolidaritáskapacitást szabadít fel (lásd még Carlsen et al. 2021: 127 kutatását). Durkheim organikus szolidaritásról és a társadalom tagjainak kölcsönös függéséről szóló elmélete különösen egy vészhelyzetben szintén borítékolhatta volna a szolidaritás növekedését, még Hondrich és Koch-Arzberger (1994) kritikája mellett is, miszerint manapság a szolidaritásmezők inkább erős szociális közösségi kötelékek, mintsem kényszerű közösségi kötődések mentén jelennek meg. A német szerzőpáros sem vitatja azonban azt, hogy közösségi vészhelyzetben az aktív szolidaritás növekszik (lásd még Goes 2015: 54). Ugyanakkor elképzelhető az is, hogy a 2015-ös migrációs krízis nyomán felkorbácsolt indulatok és morális pánik lecsengése (legalábbis az ESS 2014-2016 és 2018-as összehasonlító adatai ezt a tendenciát mutatják - saját számítások) is szerepet játszik a szolidaritás erősödésében. Biztosat ezekről a hatásokról pusztán a jelenlegi kutatás alapján nem állíthatunk e változások közvetlen okairól.

Koos és Leuffen (2020) makroszolidaritással kapcsolatos kutatása Németországban azonban rávilágított arra, hogy nem egyértelmú a pandémia és a szolidaritás inkluzív formáinak kapcsolata: a segítségnyújtás nem univerzalisztikus, vagyis számítani lehet az exkluzív szolidaritás erősödésére is. Itt kell megemlítenünk, hogy az inkluzív szolidárisok növekvő aránya mellett Magyarországon az exkluzív szolidáris csoport aránya a 2017-es értékről 2020-ra összességében egyharmadával (24 százalékról 32 százalékra) növekedett. Pozitív változás (lehetne), hogy így a valamilyen szinten (makro)szolidáris csoportok együttes prevalenciája kétharmadossá vált az 
országban (2017-ben ez csak 40 százalékra rúgott). Ezzel párhuzamosan az exkluzivitás szintje is csökkent Magyarországon, habár valamilyen fokú és „típusú” exkluzivitás (SDO, jóléti sovinizmus/populizmus vagy tekintélyelvűség) így is az aktív korúak legalább felét jellemzi. Az exkluzív szolidaritás erősödése azonban mégsem jó hír, és rögtön ki is térünk arra, hogy miért.

Eredményeink közül az inkluzív szolidáris és nonszolidáris csoport hasonló profilja nem okozott különösebb meglepetést, ahogyan az exkluzív csoportok alacsonyabb társadalmi státusza sem (ezekre a szakirodalomból és korábbi kutatási eredményeinkből következtethettünk - Grajczjár et al. 2021). Kutatásunk azonban revelatív eredményekkel is szolgált. Az exkluzív csoportok szignifikánsan alacsonyabb munkaérintettsége kifejezetten újdonságnak számít, különösen ha figyelembe vesszük azt a tendenciát, hogy a pandémia alatt elsősorban az alacsonyabb státuszúak veszítették el a munkájukat (Köllő-Reizer 2021). Az is igaz ugyanakkor, hogy mi a fizetés nélküli szabadságot, a bércsökkenést és a munkaidőcsökkenést is figyelembe vettük a munkaérintettség változó kialakításánál, vagyis egy átfogóbb munkadeprivációs mérőeszközzel dolgoztunk. Az igazi meglepetést azonban az exkluzív szolidárisok vakcinációs kockázatvállalási hajlandóságának hiánya jelentette. Miközben a saját, de különösen a közösség érdekében történő oltakozást aktivitást igénylő szolidaritásmotívumnak tekinthetjük/tekintettük, meg kell állapítanunk, hogy még a nonszolidáris klaszterek tagjai is kevésbé mutatkoznak „oltásóvatosnak”, mint az exkluzív szolidárisok. Véleményünk szerint az exkluzív szolidárisok erős kirekesztő attitűdjei (amely attitűdök a legtöbb említett kutatásban csökkentették a szolidaritást, illetve a segítségnyújtási és vakcinációs hajlandóságot, lásd például Choma et al. 2021, Pizzaro et al. 2020, Politi et al. 2020, Murphy et al. 2021), kombinálódva szektariánus egyenlősítő törekvésekkel és tribalizmussal, a közösségi kockázatvállalás/felelősségvállalás legfontosabb gátjai, amelyek megakadályozzák, hogy e csoport tagjai saját szükségleteik kielégítését az össztársadalmi érdekek miatt korlátozzák (Bayertz 1999). E csoport esetében a makroszolidáris attitűdök, a beszerzendő vakcinába és a kormányba vetett bizalom ugyan jelen vannak, de nem találkoznak a közösség iránti empátiával és aktív kockázatvállalói intencióval, vagyis ők valószínúleg nem, vagy kevéssé fognak részt venni a nyájimmunitás kialakításában.

A szolidarisztikus, aktív kockázatvállalást mint oltakozási hajlandóságot, úgy tűnik, az inkluzív és exkluzív tengely és az empátia, nem pedig a szolidaritásnonszolidaritás-tengely határozza meg egy súlyos járványhelyzetben, amikor a kockázatvállalás vélhetően olyan súlyos terhet helyez különösen az exkluzív orientációjú kérdezettek vállára, hogy talán még a saját szolidaritásközösségükhöz tartozókkal sem igazán törődnek, sokkal inkább pusztán önmagukkal. 


\section{Irodalom}

Az internetes hivatkozások utolsó letöltésének ideje: 2021. július 23.

Adorno et al. (1950): The Authoritarian Personality. New York: Harper and Row.

Aiello, A. - Areni, A. (1998): Un aggiornamento della Scala di De Grada ed altri (1975) per la misura dell'Etnocentrismo. (An updating of the attitude scale of De Grada et al (1975) for the measurement of ethnocentrism.) Rassegna di Psicologia, 15 (2): 145-160.

Alexander, J. (2012): Trauma. A Social Theory. Malden: Polity Press

Aschauer, W. - Mayerl, J. (2019): The dynamics of ethnocentrism in Europe. A comparison of enduring and emerging determinants of solidarity towards immigrants. European Societies, 21 (5): 672-703. https://doi.org/10.1080/14616 696.2019.1616791

Bayertz, K. (1999): Four uses of “solidarity”. In Bayertz, K (szerk.): Solidarity, Dordrecht: Springer. 3-28.

Beecher, J. (1986): Charles Fourier: The Visionary and his World. Berkeley: University of California Press. https://doi.org/10.1525/9780520310261

Becker, J. - Eckert, J. - Kohli, M. - Streeck, W. (2004): Transnationale Solidarität: Chancen und Grenzen. Frankfurt a. M / New York: Campus.

Bierhoff, H.-W. (2002): Prosoziales Verhalten. In Stroebe W. - Jonas K. - Hewstone M. (szerk.): Sozialpsychologie. Springer-Lehrbuch. Berlin-Heidelberg: Springer. https://doi.org/10.1007/978-3-662-08008-5_9

Carlsen, H. B. - Toubøl, J. - Brincker, B. (2021): On solidarity and volunteering during the COVID-19 crisis in Denmark: the impact of social networks and social media groups on the distribution of support. European Societies, 23 (1): 122-140 https://www.tandfonline.com/doi/ref/10.1080/14616696.2020.1818270

Choma, B. L. - Hodson, G. - Sumantry, D. et al. (2021): Ideological and Psychological Predictors of COVID-19-Related Collective Action, Opinions, and Health Compliance Across Three Nations. Journal of Social and Political Psychology, 9 (1): 123-143, https://doi.org/10.5964/jspp.5585

Csepeli Gy. - Murányi I. - Prazsák G. (2011): Új tekintélyelvúség a mai Magyarországon. Társadalmi csoportok hierarchiájának látásviszonyai. Budapest: Aperion.

Denz, H. (2003): Solidarität in Österreich. Strukturen Und Trends. SWS-Rundschau, 43(3): 321-336. http://nbn-resolving.de/urn:nbn:de:0168-ssoar-165276

Durkheim, É. (2000 [1893]): A társadalmi munkamegosztásról. Budapest: Osiris.

European Observatory on Health Systems and Policies \& Prats-Monné, Xavier (2018): Vaccination is the solidarity of the many for the few. Eurohealth, 24 (3), 38-40. World Health Organization. Regional Office for Europe. https://apps.who.int/iris/handle/10665/332547 
Gesthuizen, M. - Savelkoul, M. - Sceepers, P. (2014): Ethnic diversity and dimensions of in-group solidarity. Social Conflict within and between groups. Psychology Press, 2014 (5): 89-106.

Goes, T. (2015): Zwischen Disziplinierung und Gegenwehr. Wie Prekarisierung sich auf Beschäftigte im Großhandel auswirkt. Frankfurt: Campus Verlag.

Goreis, A. - Voracek, M. (2019): A systematic review and meta-analysis of psychological research on conspiracy beliefs: Field characteristics, measurement instruments, and associations with personality traits. Frontiers in Psychology, 10 (Feb): 1-13. https://doi.org/10.3389/fpsyg.2019.00205

Grajczjár I. - Kenéz A. (2015): A szektáriánus egyenlősítés és az ambivalens előítélet beágyazottsága a magyar társadalomban. In Grajczjár István (szerk.): Válság és radikalizmus: a Jobbik térnyerésének vizsgálatához. Budapest: MTA Társadalomtudományi Kutatóközpont Szociológiai Intézet, 12-43.

Grajczjár, I. - Nagy Zs. - Örkény A. (2019): Different types of solidarity in times of crises - a changing European landscape. Intersections. East European Journal of Society and Politics, 5 (1): 118-142. https://doi.org/10.17356/ieejsp.v5i1.475

Grajczjár, I. - Nagy Zs. - Örkény A. (2021): Types of Solidarity in a Hybrid Regime: The Hungarian Case. Government and Opposition. Cambridge University Press. (Megjelenés alatt, - 2021. október).

Hartman, T. K. et al. (2021): The Authoritarian Dynamic During the COVID-19 Pandemic: Effects on Nationalism and Anti-Immigrant Sentiment. Social Psychological and Personality Science, 20 (10): 1-12. https://journals.sagepub.com/ doi/pdf/10.1177/1948550620978023

Hentges, G. - Flecker, J. (2006): Die Sirenen-Gesänge des europäischen Rechtspopulismus. In Bathke P. - S. Spindler (szerk.): Neoliberalismus und Rechtsextremismus in Europa. Zusammenhänge - Wiedersprüche - Gegenstrategien. Berlin: Karl Dietz Verlag, 122-146.

Hiel, A. V. - Mervielde, I. (2005): Authoritarianism and social dominance orientation: Relationships with various forms of racism. Journal of Applied Social Psychology, 35 (11): 2323-2344. https://doi.org/10.1111/j.1559-1816.2005.tb02105.x

Hondrich, K. O. - Koch-Arzberger, C. (1992): Solidarität in der modernen Gesellschaft. Frankfurt am Main: Fischer Taschenbuch Verlag.

Kaindl, C. (2006): Antikapitalismus und Globalisierungskritik von rechts Erfolgskonzepte für die extreme Rechte? In Bathke, P. - Spindler, S. (szerk.): Neoliberalismus und Rechtsextremismus in Europa. Zusammenhänge - Wiedersprüche - Gegenstrategien. Berlin: Karl Dietz Verlag, 60-75.

Koos, S. - Bertogg, A. (2020): Lokale Solidarität während der Corona-Krise: Wer gibt und wer erhält informelle Hilfe in Deutschland? Research Paper. https://kops.uni-konstanz.de/handle/123456789/49942

Koos, S. - Leuffen, D. (2020): Beds or bonds? Conditional solidarity in the coronavirus crisis. https://www.progressives-zentrum.org/beds-or-bonds-covid19-inequality 
Köllő J. - Reizer B. (2021): A koronavírus-járvány első hullámának hatása a foglalkoztatásra és a vállalatok árbevételére. Közgazdasági Szemle, 68. évf., 2021. április, 345-374. https://doi.org/10.18414/KSZ.2021.4.345

Kriesi, H. (2015): Enlightened Understanding, Empowerment and LeadershipThree Ways to Enhance Multiculturalism: Comment on Will Kymlicka's article: “Solidarity in Diverse Societies". Comparative Migration Studies, 3 (1): 18. https://doi.org/10.1186/s40878-015-0019-2

Larsen, M. H, - Schaeffer, M. (2020): Healthcare chauvinism during the COVID-19 pandemic. Journal of Ethnic and Migration Studies, 47(2): 1-19.

Lenski G. E. (2013): Power and Privilege: A Theory of Social Stratification. New York: UNC Press.

Mileti, F. - Tondolo, R. - Plomb, F. - Schultheis, F. - Meyer, M. - Hentges, G. Mairhuber, I. - Flecker, J. (2002): Modern Sirens and Their Populist Songs. A European Literature Review on Changes in Working Life and the Rise of RightWing Populism. Vienna: SIREN-project Manuscript.

Murphy, J. - Vallières, F. - Bentall, R. P. et al. (2021): Psychological characteristics associated with COVID-19 vaccine hesitancy and resistance in Ireland and the United Kingdom. Nature Communications, 12 (29).

https://doi.org/10.1038/s41467-020-20226-9

Örkény A. (2020): Koronavírus-járvány a szociológia optikájából. In Fokasz Nikosz Kiss Zsuzsanna - Vajda Júlia (szerk.): Koronavírus idején. Budapest: Replika Alapítvány, 57-64.

Örkény A. (2021): A koronavírus-járvány társadalmi hatásainak lehetséges makro-, mezo- és mikroszintű problémái. Járvány és társadalom - Vírus, vakcináció, nyájimmunitás. Konferencia, 2021. február 2.

Politi, E. - Van Assche, J. - Caprara, G. V. - Phalet, K. (2020): No man is an island: Psychological underpinnings of prosociality in the midst of the COVID-19 outbreak. Personality and Individual Differences, 171 https://www.researchgate.net/ publication/345956549_No_man_is_an_island_Psychological_underpinnings_ of_prosociality_in_the_midst_of_the_COVID-19_outbreak https://doi.org/10.1016/j.paid.2020.110534

Pratto, F. - Sidanius, J. - Stallworth, L. M. - Malle, B. F. (1994): Social dominance orientation: A personality variable predicting social and political attitudes. Journal of Personality and Social Psychology, 67 (4): 741-763. http://nrs.harvard.edu/ urn-3:HUL.InstRepos:3207711 https://doi.org/10.1037/0022-3514.67.4.741

Reßler, R. (2002): Bestimmungsfaktoren zur allgemeinen Akzeptanz wohlfahrtsstaatlicher Leistungen. Mikro- und makrosoziale Determinanten. Wirtschaft und Gesellschaft, Sonderdruck, 34-28 (2): 201-228.

Rydgren, J. (2006): Vom Wohlfahrtschauvinismus zur ideologisch Begründeten Fremdenfeindlichkeit. Rechtspopulismus in Schweden und Dänemark. In 
Decker, F. (szerk.): Populismus. Gefahr für Demokratie oder nützliches Korrektiv? Wiesbaden: VS Verlag für Sozialwissenschaften, 165-190.

Sik D. - Zakariás I. (2021): A Covid-járvány első hullámának hatása a szolidaritási viszonyokra - egy online survey kutatás tapasztalatai. Kutatási jelentés. https://sites. google.com/view/keso-modern-szolidaritas/járvány-és-szolidaritás?authuser=0

Smith C. - Sorrell K. (2014): On Social Solidarity. In Jeffries V. (szerk.): The Palgrave Handbook of Altruism, Morality, and Social Solidarity. New York: Palgrave Macmillan, 219-247. https://doi.org/10.1057/9781137391865_10

Soral, W. - Bilewicz, M. (2021): The Politics of Vaccine Hesitancy: An Ideological DualProcess Approach. https://doi.org/10.31234/osf.io/djm3a

Stjernø, S. (2005): Solidarity in Europe. The History of an Idea. Cambridge: Cambridge University Press. https://doi.org/10.1017/CBO9780511490378

Szócska M. (2021): Covid-járvány és járványkezelés különböző dimenziókban. Járvány és társadalom - Vírus, vakcináció, nyájimmunitás. Konferencia, 2021. február 2.

Tragl, T. (2000): Solidarität und Sozialstaat. Teoretische Grundlagen, Probleme und Perspektiven des modernen sozialpolitischen Solidaritätskonzeptes. München, Mering: Hampp.

Voicu, B. - Peral, E. B. - Rusu, H. - Rosta, G. - Comșa, M. - Vasile, O.-M. - Coromina, L. - Tufis, C. (2021): COVID-19 and orientations towards solidarity: the cases of Spain, Hungary, and Romania. European Societies, 23 (1): 887-904. https://doi.org/10.1080/14616696.2020.1852439

Zulehner, P. M. - Denz, H. - Pelinka, A. - Tálos, E. (1996): Solidarität. Option für die Modernisierungsverlierer. Innsbruck: Tyrolia. 